\title{
PEMEROLEHAN FONOLOGI PADA KASUS AZZAHRA (0-2 TAHUN)
}

\author{
Lili Agustina ${ }^{1}$ dan Isna Kasmilawati ${ }^{2}$
}

\author{
STKIP PGRI BANJARMASIN \\ email:lili.agustina@stkipbjm.ac.id ${ }^{1}$, isna_hafiz@Stkipbjm.ac.id ${ }^{2}$
}

\begin{abstract}
ABSTRAK
Perkembangan anak dalam memperoleh bahasa di lingkungannya sangat luar biasa. Anak dengan mudah mengucapkan dan meniru apa yang didengarkan bahkan dapat menyusun sebuah rangkaian bahasa yang tidak pernah anak tersebut dengar. Pemerolehan bahasa (language acquisition) merupakan proses anak memperoleh bahasanya. Pemerolehan bahasa seperti yang dijelaskan oleh para ahli adalah identik dengan pemerolehan bahasa pertama atau bahasa ibu.

Pendekatan yang digunakan adalah pendekatan kualitatif. Teknik pengumpulan data yang dilakukan dalam penelitian ini adalah teknik simak dan teknik cakap setiap bunyi yang diucapkan oleh Azzahra. Dengan penggunaan kedua metode ini dapat membantu peneliti untuk mendapatkan data yang diperlukan. Teknik simak yang dilakukan secara alami (natural) setiap bunyi yang diucapkan oleh Azzahra.

Hasil penelitian pemerolehan bunyipada kasus Azzahra pada usia (0-1 tahun)yaitupemerolehanbunyivokal, seperti[a], [i], [e], [ ][u]. Bunyi konsonan yang terdapat padausiainiadalah $[\mathrm{b}],[\mathrm{p}],[\mathrm{m}],[\mathrm{n}],[\mathrm{d}],[\mathrm{k}],[\mathrm{y}],[\mathrm{t}]$. Polatersebut berbentuk unit suku kata yang pertama kali muncul adalah KV (konsonan dan vokal). Berdasarkan data suku kata padausiainimemiliki struktur KV,VV, KVK, KV-KV, VKV, KV-KVK. Struktur yang paling banyak ditemukan adalah KVKV. Memasukiusia (2:0) dalam pemerolehan bunyi, Zahra mampu mengucapkan fonem [o], yaitu pada kata /onti aunty/. Fonem bunyi konsonan juga bertambah dengan adanya fonem [j], [w], [s], dan [í].Pemerolehan suku kata atau silaba pada tahun kedua juga hampir sama dengan tahun pertama. Silaba yang digunakan adalah VK, KV, VKV, KV-KV, VK-VK, VK-KV, KVK, KV-KVK. Bunyi satu suku kata lebih dominan pada tahun kedua, dengan mengucapkan suku kata terakhir setiap kata, misalnya /cing/ 'kucing', /pu/ 'sapu', /num/ 'minum', /kan/ 'makan'.Berdasarkan data yang telah dikumpulkan pada kasus Azzahra, secara signifikan pemerolehan bahasa umur 2:0 tidak mengalami peningkatan yang pesat. Pada kasus Azzahra lebih banyak menunjuk untuk mengatakan sesuatu, memahami apa yang disampaikankepadanya tetapi tidak secara aktif untuk berkomunikasi di lingkunganya.
\end{abstract}

\section{PENDAHULUAN}

Perkembangan kemampuan berbahasa anak sebenarnya sudah dimulai dari anak masih dalam kandungan. Anak sudah mulai mendengarkan suara yang berasal dari luar. Hal ini dibuktikan dengan beberapa penelitian yang menyatakan bahwa anak dapat diberikan rangsangan dari luar dengan mendengarkan musik klasik atau juga dianjurkan mendengarkan lantunan ayat suci untuk meningkatkan kecerdasan sang anak. 
Setelah anak lahir, kemampuan berbahasa yang pertama kali mereka kuasai adalah menyimak suara dari apa yang didengar. Kemampuan menyimak ini adalah kemampuan yang pertama kali anak kuasai kemudian disusul dengan kemampuan berbicara atau meniru apa yang anak dengar di lingkunganya. Kemampuan berbicara yang dimiliki oleh anak masih belum dikatakan sempurna sesuai dengan fonetik bahasa Indonesia. Oleh sebab itu, penting diketahui pemerolehan bunyi dan produksi bunyi yang diucapkan oleh anak.

Topik tentang pemerolehan bunyi anak merupakan topik yang menarik. Berdasarkan topik tersebut menimbulkan beberapa pertanyaan,kapan anak mulai berbahasa, bagaimana anak berbahasa dan bagaimana anak memaknai bahasanya. Oleh sebab itu, penelitian ini berfokus memerikan bunyi-bunyi pada saat anak berumur (0-2) tahun.

Perkembangan anak dalam memperoleh bahasa di lingkungannya sangat luar biasa. Anak dengan mudah mengucapkan dan meniru apa yang didengarkan bahkan dapat menyusun sebuah rangkaian bahasa yang tidak pernah anak tersebut dengar. Beberapa teori yang yang dikemukakan oleh para ahli tentang perkembangan anak dalam berbahasa yang tidak pernah terlepas dari sudut pandang atau perspektif dan hipotesis yang pernah dilakukan. Sebut saja pandangan nativisme, behaviorisme, dan kognitivisme.

Anak memperoleh kemampuan berbahasa bukan dari pengaruh lingkungannya, melainkan anak memiliki sebuah program yang telah ada pada anak tersebut. Program tersebut adalah faktor bawaan atau faktor biologis anak. Hal ini dikemukakan oleh Chomsky (Chaer, 2015:222) bahwa anak memiliki alat pemerolehan bahasa yang dinamakan LAD (Language Acquisition Device). Alat ini merupakan pemberian biologis yang diprogramkan untuk merinci butir-butir tata bahasa. LAD yang dikemukakan oleh Chomsy juga merupakan bagian otak yang memproses bahasa anak. Oleh sebab itu, menurut pandangan ini, anak dalam mempelajari bahasa dalam jangka waktu yang singkat walaupun bahasa yang anak pelajari sangat kompleks dan rumit.

Berbanding terbalik dengan apa yang telah dikemukakan oleh Chomsky, kaum behavioris memiliki pandangan bahwa perkembangan berbahasa anak ditentukan oleh faktor di luar dirinya. Faktor tersebut adalah rangsangan lingkungan anak. Rangsangan tersebut akan lebih memperkuat kemampuan berbahasa anak, yaitu dengan adanya stimulus dan respons serta proses meniru. Kaidah gramatikal atau kaidah bahasa adalah perilaku verbal yang memungkinkan seseorang dapat menjawab atau mengatakan sesuatu (Skinner, dalam Chaer 2015:223).

Pandangan lain juga dikemukakan oleh Piaget. Pandangan ini menitikberatkan pada bidang kajian filsafat dan psikologi. Setiap anak dilahirkan dengan berbagai potensi dan bakat yang 
dimiliki. Kemampuan berbahasa juga dipengaruhi oleh kecerdasan yang dimiliki anak. Seperti yang ditegaskan oleh Piaget bahwa struktur yang kompleks dari bahasa bukanlah sesuatu yang diberikan oleh alam dan bukan pula sesuatu yang dipelajari oleh lingkungan (Piaget, dalam Chaer 2015:223). Oleh sebab itu, teori ini digolongkan konstruktivisme dan sangat berbeda dengan nativisme yang dibahas sebelumnya. Inti teori ini adalah seorang anak membangun kognitifnya dengan kemauan anak untuk termotivasi di lingkungannya. Piaget membagi menjadi empat periode perkembngan kognitif yaitu tahap sensori motor (0-1,5 tahun), tahap praoperasional (1,5-6 tahun), tahap operasional konkret (6-12 tahun), tahap operasional formal (12 tahun ke atas), (Ibda, 32:2015).

\begin{tabular}{|l|l|l|}
\hline USIA & TAHAP & KARAKTERISTIK \\
\hline 0 sampai 1,5-2 th & Sensorimotorik & $\begin{array}{l}\text { Prasimbolik dan praverbal; kecerdasan } \\
\text { mencakup perkembangan pola tindak; } \\
\text { mampu membedakan ciri fisiknya; dan } \\
\text { mulai tumbuhnya konsep tetap mengenai } \\
\text { suatu objek }\end{array}$ \\
\hline 2-3 sampai 7-8 th & Praoperasional & $\begin{array}{l}\text { Pikiran logis parsial mulai tumbuh; konsep } \\
\text { ketetapan suatu objek mengarahkan pada } \\
\text { identitas kualitas; proses pikiran bertolak } \\
\text { dari isyarat perseptual dan anak belum } \\
\text { sadar akan pernyataan yang saling } \\
\text { bertentangan; perkembangan Bahasa } \\
\text { dimulai dan bertambah dengan cepat; } \\
\text { bicara spontan didominasi monolog. }\end{array}$ \\
\hline 7-8 sampai 12-14 th & Operasi Konkret & $\begin{array}{l}\text { Perilaku impulsif mulai diganti dengan } \\
\text { refleksi dasar dan anak mulai dapat } \\
\text { membedakan perbedaan pandangan orang } \\
\text { lain; mulai bermain bersama termasuk } \\
\text { kesepakatan aturan dan kerja sama; cara } \\
\text { berpikir logis terkait dengan objek }\end{array}$ \\
\hline Lebih dari 14 th & Operasi Formal & $\begin{array}{l}\text { Pikiran tentang rencana hidup dan peran } \\
\text { orang dewasa mulai tumbuh; kemampuan } \\
\text { berpikir logis dalam berbagai situasi mulai } \\
\text { tumbuh; individu mampu bernalar dari } \\
\text { situasi hipotesis sampai konkret }\end{array}$ \\
\hline
\end{tabular}

Berbagai teori yang dikemukakan oleh para ahli mengenai perkembangan bahasa. Perkembangan bahasa yang akan dikaji dalam penelitian ini adalah pemerolehan fonologi anak 
usia 0-2 tahun yang sangat terbatas.Pada kasus Azzahra, setelah melewati tahap membabel (babbling) terjadi penurunan dalam berbahasa. Pada awalnya aktif dalam mengeluarkan vokal dan konsonan (tanpa tujuan) ketikamemasuki usia (1:3) terjadinya kesenyapan dengan tidak meningkatnya kosakata yang diucapkan oleh Azzahra. Adanya peralihan dalam tahap membabel dan tahap mengeluarkan bunyi yang sebenarnya. Oleh sebab itu, peneliti tertarik untuk meneliti peralihan kedua fase ini dengan kasus pemerolehan Azzahra (0-2).

\section{METODE}

Pendekatan yang digunakan dalam penelitian ini adalah pendekatan kualitatif. Pendekatan kualitatif diharapkan mampu menghasilkan suatu uraian tentang ucapan, tulisan, dan perilaku yang dapat diamati/dilihat dari suatu individu.Kualitatif sebagai proses penelitian yang menghasilkan data deskriptif berupa data tertulis atau lisan dari objek yang mauditeliti. Penelitian deskriptif pada umumnya dilakukan dengan tujuan utama, yaitu menggambarkan secara sistematis fakta dan karakteristik objek dan subjek yang diteliti secara tepat. Data yang terkumpul diklasifikasikan atau dikelompok-kelompokan menurut jenis, sifat, atau kondisinya, setelah datanya lengkap, kemudian dibuat simpulan.Secara khusus pendekatan ini menggunakan pendekatan psikolinguistik. Psikolinguistik adalah kajian yang membahas psikologi dan linguistik. Psikolinguistik adalah linguistik terapan. Seperti yang dikemukakan oleh Kes (Budhiono, 2010:165) mengatakan bahwa psikolinguistik adalah ilmu yang mempelajari aspek psikologis dalam studi bahasa.

Subjek dalam penelitian ini adalah Azzaahra yang merupakan anak sendiri dari peneliti. Lahir di Banjarmasin, 21 Juli 2018.Teknik pengumpulan data yang dilakukan dalam penelitian ini adalah teknik simak dan teknik cakap setiap bunyi yang diucapkan oleh Azzahra. Dengan penggunaan kedua metode ini dapat membantu peneliti untuk mendapatkan data yang diperlukan. Teknik simak yang dilakukan dilakukan secara alami (natural) setiap bunyi yang diucapkan oleh Azzahra.

\section{HASIL DAN BAHASAN}

Pemerolehan bahasa (language acquisition) merupakan proses anak memperoleh bahasanya. Pemerolehan bahasa seperti yang dijelaskan oleh para ahli adalah identik dengan pemerolehan bahasa pertama atau bahasa ibu. Seperti yang telah diketahui, semua anak akan memperoleh bahasanya. Hal ini disebabkan karena anak memiliki peranti berbahasa yang dibawa 
sejak lahir yang dinamakan LAD (Language Acquisition Device). Dengan adanya LAD anak mempunyai kemampuan untuk memperoleh bahasanya. (Chomsky, dalam Chaer (2009:170).

Perkembangan dalam menghasilkan bunyi atau artikulasi seperti yang dikemukakan oleh Dardjowidjojo (Budhiono, 2011:166)memiliki tahapan-tahapan sebagai berikut:

1. cooing atau mendekut, yaitu produksi bunyi yang mirip vocal dan konsonan dan terjadi pada usia sekitar 2-5 bulan,

2. babbling atau celoteh, yaitu produksi bunyi yang berupa suku kata yang terjadi pada usia sekitar 9-18 bulan,

3. one-word utterances, yaitu tahap ujaran satu kata yang terjadi pada usia sekitar 9-18 bulan,

4. two-word utterances, yaitu produksi ujaran dua kata yang terjadi pada usia sekitar 18-24 bulan,

5. tahap telegrafis, yaitu tahap produksi kalimat sederhana yang terjadi pada usia sekitar 24-30 bulan, dan

6. tahap multikata lanjut, yaitu produksi kalimat yang sudah bias dikatakan gramatikal dan terjadi pada usia lebih dari 30 bulan.

\section{PEMEROLEHAN FONOLOGIS}

\section{TAHUN PERTAMA}

Tahap pemerolehan bahasa Azzahra 3-5 bulandimulaidarimendekut.Bunyi yang munculsepertibunyivokal [o], [r], [b].Kemampuan mendengarkan yang dimiliki oleh Zahra lebih dominan pada fase ini. Zahra mulai merespons dari bunyi yang didengarnya. Respons yang terlihat adalah dengan tangisan dan senyuman, kemudian diikuti dengan membabel. Menurut Ingram (Chaer, 2009:214) membabel bukanlah kegiatan semaunya melainkan merupakan suatu kegiatan yang agak teratur dan maju berkelanjutan. Membabel bukan merupakan suatu latihan, melainkan ada hubungannya dengan seluruh proses pemerolehan fonologi. Mendekati umur (1:0)tahun, Azzahra sudah mulai memasuki tahap fonologi primitif dengan mengucapkan satu ujaran kata maman (ketika melihat makanan).

Dalam pemerolehan fonologi sangat dipenggaruhi oleh lingkungan. Anak mulai mendengar dan mengamati bahasa yang berada di sekitarnya. Proses meniru atau mengikuti bahasa yang didengar dilakukan oleh Azzahra dalam hal pemerolehan bahasa. Dengan pola pengucapan berulang oleh lingkungan menjadi pola pemerolehan bahasa anak terutama fonologi. Hal ini sangat dibantu dengan adanya konteks yang menyertai sehingga anak mulai belajar yang berkaitan 
dengan makna/semantik. Contoh kata eki(namakucing) hanya digunakan oleh Azzahra ketika melihat ada kucing.

Pemerolehan bunyi vokal terdapat pada pemerolehan bahasa Zahra adalah seperti vokal [a] pada kata /ayi/ yang bermakna /kai/ atau /kakek/. Fonem [e] yang diucapkan seperti pada kata /eki/ yaitu kucing yang hitam (blacky) dan /ee/ diucapkan pada saat mau BAB. Paling banyak ditemukan adalah fonem [a], dan [i],yang berada pada akhir suku kata, seperti pada kata /ba-ba/, /ma-ma/, /ni-ni/, /ya-yah/, /da-dah/, /ma-man/, dan /bu-bah/.

Dalam halnya bunyi konsonan yang tidak jauh berbeda dengan pendapat para ahli sebelumnya, pada kasus Azzahra bunyi dimulai dengan bunyi konsonan yaitu bunyi bibir (bilabial) atau bunyi konsonan yang terjadi pada kedua belah bibir; bibir bawah merapat pada bibir atas seperti pada [b], [p] dan [m]. Hal ini terdengar ketika mengucapkan kata [baba], [papa] dan [mama]. Berdasarkan bunyi tersebut, Zahra lebih suka menggunakan perulangan suku kata. Bunyi konsona lain juga ditemukan, yaitu laminoalveolar, yaitu bunyi [t] dan [d] pada kata /ti/ dan /dadah/. Pada usia (1:0) Azzahra tidak bisa mengucapkan fonem [o]. Oleh sebab itu, seharusnya /aunty/ diucapkan /ti/ oleh Zahra.

Bunyi konsonan yang ditemukan pada usia ini adalah[n] yang merupakan bunyi nasal. Bunyi konsonannasal [n] diucapkan dengan bersamaan bunyi vokal [i] seperti pada kata/nini/. Hampiran juga ditemukan pada usia ini, ditemukan bunyi [y] pada kata /yayah/, /ayi/. Berdasarkan hasil rekaman dan pengamatan yang telah dilakukan terdapat data-data fonem vokal dan konsonan pada kasus Azzahra, yaitu sebagai berikut.

Tabel 1

Distribusi Vokal Azzahra (1:0Tahun)

\begin{tabular}{|c|c|c|c|}
\hline \multirow{2}{*}{ Fonem } & \multicolumn{3}{|c|}{ Posisi Kata } \\
\cline { 2 - 4 } & Awal & Tengah & $\sqrt{ }$ \\
\hline$[\mathrm{a}]$ & $\sqrt{ }$ & $\sqrt{ }$ & $\sqrt{ }$ \\
\hline$[\mathrm{i}]$ & - & - & - \\
\hline$[\mathrm{e}]$ & $\sqrt{ }$ & - & - \\
\hline[] & $\sqrt{ }$ & $\sqrt{ }$ & $\sqrt{ }$ \\
\hline$[\mathrm{u}]$ & - & & \\
\hline
\end{tabular}


Tabel 2

Distribusi Konsonan Azzahra (1:0Tahun)

\begin{tabular}{|c|c|c|c|}
\hline \multirow{2}{*}{ Fonem } & \multicolumn{3}{|c|}{ Posisi Kata } \\
\cline { 2 - 4 } & Awal & Tengah & Akhir \\
\hline$[\mathrm{b}]$ & $\sqrt{ }$ & - & - \\
\hline$[\mathrm{p}]$ & $\sqrt{ }$ & - & $\sqrt{ }$ \\
\hline$[\mathrm{m}]$ & $\sqrt{ }$ & - & - \\
\hline$[\mathrm{n}]$ & $\sqrt{ }$ & $\sqrt{ }$ & - \\
\hline$[\mathrm{d}]$ & - & $\sqrt{ }$ & - \\
\hline$[\mathrm{k}]$ & $-\sqrt{ }$ & - & - \\
\hline$[\mathrm{y}]$ & $\sqrt{\mathrm{n}}$ & $\sqrt{ }$ & - \\
\hline$[\mathrm{t}]$ & & & \\
\hline
\end{tabular}

Pemerolehan suku kata pada kasus Azzahra (0:1) tahun berbentuk unit suku kata yang pertama kali muncul adalah KV konsonan dan vokal. Hal ini terlihat dari /ma/, kemudian diikuti dengan KVK, VK dan V. KVK pada pemerolehan fonologi. Berdasarkan tabel di atas terlihat bahwa pemerolehan fonologi yaitu memiliki struktur KV, V, VV, KVK, KVKV, VKV, KVKVK. Struktur yang paling banyak ditemukan adalah KVKV. Penggunaan vokal [a], [i], [e], [u] /i/ digunakan oleh Zahra. Paparan data di bawah ini terlihat pemerolehan fonologi lebih dominan menggunakan suku kata yang sama, seperti /mama/, /nini/, /dadah/,/mamam/ dsbnya. Hal ini terlihat dalam tabel 3 di bawah ini.

Tabel 3

Pemerolehan Kata (1:0 Tahun)

\begin{tabular}{|c|c|}
\hline Kata & Makna \\
\hline /ma/ & mama \\
\hline /mama/ & mama \\
\hline /babah/ & ayah \\
\hline /nini/ & nenek \\
\hline /ayi/ & kakek \\
\hline /yayah/ & zahra \\
\hline /mamam/ & makan \\
\hline
\end{tabular}




\begin{tabular}{|c|c|}
\hline /dadah/ & dadah \\
\hline /bubah/ & burung \\
\hline /eki/ & blacky/kucing \\
\hline /ti/ & onty/aunty \\
\hline /ee/ & BAB \\
\hline
\end{tabular}

\section{TAHUN KEDUA}

Pada tahun kedua ini pertambahan pemerolehan bunyi tidak banyak. Hal ini ditandai dengan penurunan keaktifan dalam melatih bicaranya pada umum (1:6). Hal ini bisa dikatakan kesenyapan sementara. Aktivitas komunikasi lebih banyak menggunakan isyarat seperti menunjuk, menarik tangan atau barang dan lainnya.

Dalam pemerolehan bunyi, , Zahra mampu mengucapkan fonem [o], yaitu pada kata /onti aunty/. Fonem bunyi konsonan juga bertambah dengan adanya fonem [j], [w], [s], dan [í]. Oleh sebab itu, dalam tabel yang tersaji di bawah ini terlihat pemerolehan fonem yang diperoleh pada tahun kedua.

Tabel 4

Distribusi Vokal Azzahra (2:0 Tahun)

\begin{tabular}{|c|c|c|c|}
\hline \multirow{2}{*}{ Fonem } & \multicolumn{3}{|c|}{ Posisi Kata } \\
\cline { 2 - 4 } & Awal & Tengah & Akhir \\
\hline$[\mathrm{a}]$ & $\sqrt{ }$ & $\sqrt{ }$ & $\sqrt{ }$ \\
\hline$[\mathrm{i}]$ & $\sqrt{ }$ & - & - \\
\hline$[\mathrm{e}]$ & $\sqrt{ }$ & - & - \\
\hline[] & $\sqrt{ }$ & - & - \\
\hline$[\mathrm{u}]$ & - & - & $\sqrt{ }$ \\
\hline$[\mathrm{O}]$ & $\sqrt{ }$ & & \\
\hline
\end{tabular}


Tabel 5

Distribusi Konsonan Azzahara (2:0 Tahun)

\begin{tabular}{|c|c|c|c|}
\hline \multirow[t]{2}{*}{ Fonem } & \multicolumn{3}{|c|}{ Posisi Kata } \\
\hline & Awal & Tengah & Akhir \\
\hline [b] & $\sqrt{ }$ & - & - \\
\hline [c] & - & $\sqrt{ }$ & $\sqrt{ }$ \\
\hline [d] & $\sqrt{ }$ & $\sqrt{ }$ & - \\
\hline [j] & - & $\sqrt{ }$ & - \\
\hline$[\mathrm{k}]$ & - & $\sqrt{ }$ & - \\
\hline$[\mathrm{m}]$ & $\sqrt{ }$ & $\sqrt{ }$ & $\sqrt{ }$ \\
\hline$[\mathrm{n}]$ & $\sqrt{ }$ & - & - \\
\hline [p] & $\sqrt{ }$ & - & - \\
\hline$[\mathrm{s}]$ & - & - & $\sqrt{ }$ \\
\hline$[\mathrm{t}]$ & $\sqrt{ }$ & - & - \\
\hline [w] & $\sqrt{ }$ & - & - \\
\hline [y] & $-\sqrt{ }$ & $\sqrt{ }$ & - \\
\hline [门́] & - & - & $\sqrt{ }$ \\
\hline
\end{tabular}

Pemerolehan suku kata atau silaba pada tahun kedua juga hampir sama dengan tahun pertama. Silaba yang digunakan adalah VK, KV, VKV, KV-KV, VK-VK, VK-KV, KVK, KVKVK. Bunyi satu suku kata lebih dominan pada tahun kedua, dengan mengucapkan suku kata terakhir setiap kata, misalnya /cing/ 'kucing', /pu/ 'sapu', /num/ 'minum', /kan/ 'makan'. Hal ini bisa terlihat di tabel di bawah ini.

\section{Tabel 6}

Pemerolehan Kata(2:0 Tahun)

\begin{tabular}{|c|c|}
\hline Kata & Makna \\
\hline /mama/ & mama \\
\hline /babah/ & ayah \\
\hline /nini/ & nenek \\
\hline /ayi/ & kakek \\
\hline
\end{tabular}




\begin{tabular}{|c|c|}
\hline /yayah/ & zahra \\
\hline /mamam/ & makan \\
\hline /icem/ & ice cream \\
\hline /onti/ & aunty \\
\hline /anja/ & belanja \\
\hline /wit/ & duit \\
\hline /kan/ & ikan \\
\hline /num/ & minum \\
\hline /is/ & es \\
\hline /cing/ & kucing \\
\hline /pu/ & sapu \\
\hline
\end{tabular}

Berdasarkan data yang telah dikumpulkan pada kasus Azzahra, secara signifikan pemerolehan bahasa usia(2:0) tahuntidak mengalami peningkatan yang pesat. Pada kasus Azzahra lebih banyak menunjuk untuk mengatakan sesuatu. Pada kasus Azzahra, memahami apa yang disampaikan kepadanya tetapi tidak secara aktif untuk berkomunikasi di lingkunganya. Lingkungan di sekitar Azzahra dapat dikatakan selalu aktif untuk mendorongnya untuk bisa berbicara. Umur ini jg menandai bahwa anak tidak ingin meniru apa yang didengarnya. Hal ini berbeda dengan umur 1:0 yang aktif dalam meniru kata yang telah didengarnya di lingkungan terutama rumah. Pada umur ini menandakan bahwa anak tidak serta merta mengikuti lingkunganya. Seperti halnya yang dikemukakan oleh Piaget, bahwa kecerdasan anak sangat berpengaruh terhadap pemerolehan bahasanya. Program bawaan atau lingkungan tidak secara signifikan mempengaruhi pemerolahan bahasa anak. Hal ini tergantung anak yang ikut serta aktif dalam lingkunganya. Oleh sebab itu, faktor ini yang menyebabkan setiap anak cepat dalam memperoleh bahasanya seperti kosakata yang dikuasai telah banyak dan juga lambat dalam memperoleh bahasanya, kosakata yang dikuasai masih minim.

\section{SIMPULAN}

Dalam pemerolehan fonologi sangat dipenggaruhi oleh lingkungan. Anak mulai mendengar dan mengamati bahasa yang berada di sekitarnya. Proses meniru atau mengikuti bahasa yang didengar dilakukan oleh Azzahra dalam hal pemerolehan bahasa. Dengan pola pengucapan 
berulang oleh lingkungan menjadi pola pemerolehan bahasa anak terutama fonologi. Hal ini sangat dibantu dengan adanya konteks yang menyertai sehingga anak mulai belajar yang berkaitan dengan makna/semantik.

Pemerolehan bunyipada kasus Azzahra pada usia (0-1 tahun)yaitupemerolehanbunyivokal, seperti[a], [i], [e], [ ], [u]. Bunyi konsonan yang terdapat padausiainiadalah[b], [p], [m], [n], [d], [k], [y], [t]. Polatersebut berbentuk unit suku kata yang pertama kali muncul adalah KV (konsonan dan vokal). Berdasarkan data suku kata padausiainimemiliki struktur $\mathrm{KV}, \mathrm{VV}, \mathrm{KVK}, \mathrm{KV}-\mathrm{KV}$, VKV, KV-KVK. Struktur yang paling banyak ditemukan adalah KVKV. Memasukiusia (2:0) dalam pemerolehan bunyi, Zahra mampu mengucapkan fonem [o], yaitu pada kata /onti aunty/. Fonem bunyi konsonan juga bertambah dengan adanya fonem [j], [w], [s], dan [门́].Pemerolehan suku kata atau silaba pada tahun kedua juga hampir sama dengan tahun pertama. Silaba yang digunakan adalah VK, KV, VKV, KV-KV, VK-VK, VK-KV, KVK, KV-KVK. Bunyi satu suku kata lebih dominan pada tahun kedua, dengan mengucapkan suku kata terakhir setiap kata, misalnya /cing/ 'kucing', /pu/ 'sapu', /num/ 'minum', /kan/ 'makan'.

Berdasarkan data yang telah dikumpulkan pada kasus Azzahra, secara signifikan pemerolehan bahasa umur 2:0 tidak mengalami peningkatan yang pesat. Pada kasus Azzahra lebih banyak menunjuk untuk mengatakan sesuatu. Pada kasus Azzahra, memahami apa yang diperintahkan kepadanya tetapi tidak secara aktif untuk berkomunikasi di lingkunganya. Lingkungan di sekitar Azzahra dapat dikatakan selalu aktif untuk mendorongnya untuk bisa berbicara. Umur ini jg menandai bahwa anak tidak ingin meniru apa yang didengarnya. Hal ini berbeda dengan umur 1:0 yang aktif dalam meniru kata yang telah didengarnya di lingkungan terutama rumah. Pada umur ini menandakan bahwa anak tidak serta merta mengikuti lingkunganya. Seperti halnya yang dikemukakan oleh Piaget, bahwa kecerdasan anak sangat berpengaruh terhadap pemerolehan bahasanya. Program bawaan atau lingkungan tidak secara signifikan mempengaruhi pemerolahan bahasa anak. Hal ini tergantung anak yang ikut serta aktif dalam lingkungnanya. Oleh sebab itu, faktor ini yang menyebabkan setiap anak cepat dalam memperoleh bahasanya seperti kosakata yang dikuasai telah banyak dan juga lambat dalam memperoleh bahasanya, kosakata yang dikuasai masih minim.

\section{DAFTAR RUJUKAN}

Andini, Hollysa. 2018. Pemerolehan Bahasa Indonesia pada Anak Usia 0-2 Tahun Kajian Psikolonguistik. Jurnal Lingua, Vol. 15, No. 1, Maret 2018. 
Budhiono, R. Hery. 2011. PemerolehanFonologispadaAnak Usia1-2 Tahun. JurnalAdabiyyat.Vo. 10, No. 1, Juni 2011.

Chaer, Abdul. 2009. Psikolinguistik: Kajian Teoritik. Jakarta: Rineka Cipta.

Chaer, Abdul. 2015. Morfologi Bahasa Indonesia (Pendekatan Proses). Jakarta: Rineka Cipta.

Ibda, Fatimah. 2015. Perkembangan Kognitif: Teori Jean Piaget. Jurnal Intelektualita. Vol. 3, No. 11, Januari-Juni 2015.

Mahsun. 2017. Metode Penelitian Bahasa, Tahapan, Strategi, Metode dan Tekniknya. Depok. Raja Grafindo Persada.

Muslich, Masnur. 2008. Fonologi Bahasa Indonesia. Jakarta: Bumi Aksara. 